\title{
Assessment of Nurses' Knowledge Concerning Protein Energy Malnutrition for Children under Age Five Years at Medical Wards in \\ Baghdad City
}

Asmahan Qasim Mohammed* Mohammed Ahmed Sultan** Suzan Ali Abdulhassan*** ABSTRACT

Background and objective: The protein energy malnutrition represents as a major health problem in the Iraq. It occurs particularly in weaklings and children in the first year. This study aims to identify the nurses' knowledge regarding protein energy malnutrition for children under age five years at medical pediatric wards in Baghdad city

Materials and method: A descriptive study was carried out in the pediatric ward of teaching hospitals in Baghdad City to assessment of nurses' knowledge concerning protein energy malnutrition for children under age five years from $2^{\text {ed }}$ of May till $20^{\text {ed }}$ of December 2016. A non- probability (purposive) sample. This sample consisted of (33) nurses. The questionnaire was constructed and provided for nurses which consists of four parts. The validity of the questionnaire tool was established through a panel of experts. The reliability of evaluating statistically, a pilot study was carried out for (6) nurses selected randomly (excluded from study results).

Results: The socio-demographic characteristic of the study presents that $84.8 \%$ of them females, $54.5 \%$ of them Single, $39.4 \%$ at age (26-35) years old, $75.8 \%$ of them have (1-7) years of general experience, $39.4 \%$ graduated from Junior Nursing.

Conclusions: Majority of nurses have poor knowledge about Kwashiorkor, miasmas, and nursing management. There is significant differences between demographic characteristics such as age, level of education, and years of general employments with nurses Knowledge.

Recommendations: A extensive programs, training and workshops about protein energy malnutrition for children under age five years should be designed and implement.

Keywords: Assessment, Nurse's knowledge, protein energy malnutrition.

\section{INTRODUCTION}

The food is an every important and basic biological need for the children, It is essential for growth and development, repair of the body, regulation the mechanisms of the body and production of energy. The nutrition of people and especially children on a global level is of great concern today particularly in developing nations. As the reported studies that the population does not get enough food to eat children and their diets are deficient in enough food to eat and there are deficient in calories for that reason the children in the developing countries suffer from malnutrition (Basavanthappa, 2011).

Malnutrition of children is the one biggest contribution to the child under five mortality due to the major susceptibility to infection and show recovery from disease.The Children who do not reach optimum size as adult may have less physical capacity for works, also their brains are influenced and they are at major risk of infection which kills many children during their early years. Protein energy malnutrition is defined as a range of pathological conditions arising from coincident lack of varying proportions of proteins and calorie, occurring most frequently in infants and young children and often associated with infection (Ahmed et al., 2016).

Malnutrition is the result of many factors such as inadequate food intake (arise from poor access to food), inappropriate feeding ,frequent illness, insufficient health services, caring practices, and poor environment sanitation and poverty (Holmes, 2007).

Iyengar et al. (2009).represented as one of the most acute protein malnutrition disease between children in all the world. marasmus is said to be a protein calories malnutrition, but what sets Kwashiorkor apart from marasmus is usually the presence of edema that is typically seen in the feet, there signs of this disease include a distended abdomen, an enlarged liver, loss of teeth, thinning hair which is normally ends up (coarse) in texture, skin depigmentation and dermatitis. The children that suffering from this condition usually normally end up developing

\footnotetext{
* Assistant Lecturer/ College of Nursing / University of Baghdad.

** Assistant Lecturer/College of Nursing / University of Mosul .

*** Academic Nurse / College of Nursing / University of Baghdad.
} 
irritability and anorexia.

The World Health Organization report estimates that Globally, around 9.2 million under 5 children died, also that mortality of children aged less than 5 years is 68 per 1000 live birth $27 \%$. And about 10 million from children were dying every year, of which $40 \%$ were newborn in their first month. It concluded that the majority of the children deaths resulted from infectious disease and malnutrition associated with more than $40 \%$ and $56 \%$ of all early deaths respectively (Park, 2005).

Malnutrition is a health problems, especially children under 5 years of age. Globally, there are $15 \%$ of world's populations, who are having problem of malnutrition according to FAO reports (Kavitha, 2015).

According to the report of International Children's Emergency Fund of United Nations in 2007 that acute malnutrition is the cause of $50 \%$ of deaths of children under five years in the developing countries. Over 7,000 malnourished children had been surveyed and about 1,000 of them being affected by severe acute malnutrition, and is usually considered as one of the major causes of the children mortality (Mogahed, 2011).

Protein energy malnutrition is a major health and nutrition problem in Iraq. It occurs particularly in weaklings and children in the first year or life. It is not only an important cause of childhood mortality and morbidity but also leads constant physical impairment and possible of mental growth of those who survive. The current concept of protein energy malnutrition is that of clinical forms - Kwashiorkor and Marasmus (Kumari, 2016).

\section{MATERIALS AND METHOD}

A descriptive study was carried out at pediatric ward of Teaching Hospitals in Baghdad City to Assessment of Nurses' knowledge Concerning protein energy malnutrition for Children under age five years from $2^{\text {ed }}$ of May till $20^{\text {ed }}$ of December 2016. The study was

\section{RESULTS}

Table (1): Social and Demographic Characteristics of the Respondents in the Study

\begin{tabular}{||l|c|c|c||}
\hline \multirow{2}{*}{ Items } & & Freq. & \% \\
\hline \multirow{2}{*}{ Marital status } & Male & 5 & 15.2 \\
\cline { 2 - 4 } & Female & 28 & 84.8 \\
\hline \multirow{3}{*}{ Age } & Single & 18 & 54.5 \\
\cline { 2 - 4 } & Married & 15 & 45.5 \\
\cline { 2 - 4 } & $<=25$ & 11 & 33.3 \\
\cline { 2 - 4 } & $26-35$ & 13 & 39.4 \\
\cline { 2 - 4 } & $36-45$ & 8 & 24.2 \\
\cline { 2 - 4 } & $46=>$ & 1 & 3.0 \\
\hline
\end{tabular}

conducted at hospitals in Baghdad City were pediatric medical ward available in selected hospitals of Baghdad city (Ibn Al Baladi Teaching hospital, Child Welfare Teaching Hospital, Child's Central Hospital and Children KadhimiyaTeaching Hospital). A nonprobability (purposive) sample was chosen for the current study. The sample consisted of (33) nurses working in the pediatric medical ward of selected hospital. This is due to the shortage of nursing staff and high number of children patients in the ward. The questionnaire was constructed and provided for nurses to assess the knowledge which consists of four parts. The first part concern the demographic information, while the second part was related to the nurses knowledge in concern to malnutrition in general. The third part of the questionnaire dealt with nurse's knowledge in relation to types of malnutrition, acute and chronic malnutrition (wasting, stunting and Underweight), while the part four put emphasis on the nurse's knowledge about to nursing management of malnutrition, lack of protein and energy. The validity of the questionnaire tool were established through a panel of experts whom specified the content clarity, relevance, and adequacy. To evaluate statistically the reliability of instruments, a pilot study was carried out during the period from $2^{\text {ed }}$ of May up to the $20^{\text {ed }}$ of May of 2016. Randomly (6) nurses were selected from Child Welfare Teaching Hospital (this sample was excluded from the original study sample).The Pearson's coefficient of correlation results are $(r=0.786)$ and are significant at $p \leq 0.000$ level was used to estimate the scale (test - retest) by using SPSS version 20. Statistical methods were used in order to assess and analyze the results of the study through the application of descriptive statistics (Mean, Frequency, Percentage, Standard deviation, Pearson coefficient correlation) by using the Statistical Package for the Social Sciences(SPSS) program version 20. 


\begin{tabular}{|c|c|c|c|}
\hline Items & & Freq. & $\%$ \\
\hline \multirow{4}{*}{$\begin{array}{l}\text { Years of } \\
\text { Employments }\end{array}$} & $1-7$ & 25 & 75.8 \\
\hline & $8-14$ & 4 & 12.1 \\
\hline & $15-21$ & 2 & 6.1 \\
\hline & $22-28$ & 2 & 6.1 \\
\hline \multirow{4}{*}{$\begin{array}{l}\text { Years in The medical } \\
\text { pediatric ward }\end{array}$} & $1-7$ & 28 & 84.8 \\
\hline & $8-14$ & 1 & 3.0 \\
\hline & $15-21$ & 3 & 9.1 \\
\hline & $22-28$ & 1 & 3.0 \\
\hline \multirow{3}{*}{ Educational Level } & junior nursing & 13 & 39.4 \\
\hline & Institute of Nursing & 12 & 36.4 \\
\hline & Bachelor of Nursing & 8 & 24.2 \\
\hline \multirow{2}{*}{$\begin{array}{l}\text { Participation in Training } \\
\text { Courses }\end{array}$} & Yes & 22 & 66.7 \\
\hline & No & 11 & 33.3 \\
\hline
\end{tabular}

Table (2): Nurse's Responses Results in Concerning the Malnutrition (Lack of Protein and Energy) Knowledge

\begin{tabular}{|c|c|c|c|c|}
\hline \multirow[t]{2}{*}{ Nurses knowledge } & \multicolumn{2}{|c|}{ Assessment Degree } & \multirow{2}{*}{$\frac{\text { Frequency }}{6}$} & \multirow{2}{*}{$\begin{array}{c}\text { Percent } \\
18.2 \\
\end{array}$} \\
\hline & failure & $0-2$ & & \\
\hline \multirow{4}{*}{$\begin{array}{l}\text { Nurses knowledge in concern to } \\
\text { malnutrition in general }\end{array}$} & poor & $3-4$ & 14 & 42.4 \\
\hline & good & $6-8$ & 10 & 30.3 \\
\hline & very good & $9-10$ & 1 & 3.0 \\
\hline & excellent & $11-12$ & 2 & 6.1 \\
\hline \multirow{5}{*}{$\begin{array}{l}\text { Nurse's knowledge in relation to } \\
\text { types of malnutrition, acute and } \\
\text { chronic malnutrition (wasting, } \\
\text { stunting and Underweight) }\end{array}$} & failure & $0-2$ & 5 & 15.2 \\
\hline & poor & $3-4$ & 16 & 48.5 \\
\hline & good & $6-8$ & 11 & 33.3 \\
\hline & very good & $9-10$ & 1 & 3.0 \\
\hline & excellent & $11-12$ & 0 & 0.0 \\
\hline \multirow{5}{*}{$\begin{array}{l}\text { Nurse's knowledge about to } \\
\text { nursing management } \\
\text { malnutrition, lack of protein and } \\
\text { energy }\end{array}$} & failure & $0-2$ & 5 & 15.2 \\
\hline & poor & $3-4$ & 15 & 45.5 \\
\hline & good & $6-8$ & 11 & 33.3 \\
\hline & very good & $9-10$ & 1 & 3.0 \\
\hline & excellent & $11-12$ & 1 & 3.0 \\
\hline \multirow{5}{*}{ Total Knowledge Score } & failure & $0-6$ & 3 & 9.1 \\
\hline & poor & $7-12$ & 14 & 42.4 \\
\hline & good & $13-20$ & 10 & 30.3 \\
\hline & very good & $21-25$ & 5 & 15.2 \\
\hline & Excellent & $26-32$ & 1 & 3.0 \\
\hline Total & & & 33 & 100.0 \\
\hline
\end{tabular}

Table (3): Statistical Differences Result in Concerning the Malnutrition (Lack of Protein and Energy) Knowledge

\begin{tabular}{|l|c|c|c||}
\hline Domains & Mean & Std. Deviation & N \\
\hline $\begin{array}{l}\text { Nurses knowledge in concern to } \\
\text { malnutrition in general }\end{array}$ & 5.55 & 1.938 & 33 \\
\hline $\begin{array}{l}\text { Nurse's knowledge in relation to types of } \\
\text { malnutrition, acute and chronic malnutrition } \\
\text { (wasting, stunting and Underweight) }\end{array}$ & 5.18 & 1.960 & 33 \\
\hline $\begin{array}{l}\text { Nurse's knowledge about to nursing } \\
\text { management of malnutrition, lack of protein } \\
\text { and energy }\end{array}$ & 5.61 & 2.715 & 33 \\
\hline Total Knowledge Score & 16.48 & 5.455 & 33 \\
\hline
\end{tabular}


Table (4): Statistical Differences between Socio-demographic characteristics and Total Nurse's Knowledge Score about Malnutrition (Lack of Protein and Energy).

\begin{tabular}{||l|c|c||}
\hline \multirow{2}{*}{ Domains } & \multicolumn{2}{|c|}{ Total Knowledge Score } \\
\cline { 2 - 3 } & P -value & Sig. \\
\hline Age & 0.085 & S \\
\hline Gender & 0.346 & NS \\
\hline Marital status & 0.353 & NS \\
\hline Education Level & 0.025 & S \\
\hline Years of General Employments & 0.065 & S \\
\hline Years in The medical pediatric ward & 0.737 & NS \\
\hline the participation in training courses & 0.889 & NS \\
\hline Hospital works & 0.574 & NS \\
\hline
\end{tabular}

\section{DISCUSSION}

The socio-demographic characteristic of the present study as shown in Table (1) presents that $84.8 \%$ of them females, $54.5 \%$ of them Single, $39.4 \%$ at age (26-35) years old, $75.8 \%$ of them have (1-7) years of general experience, $84.8 \%$ of them have (1-7) years of experience inside the medical pediatric ward , $39.4 \%$ graduated from Junior Nursing and lastly $66.7 \%$ participated in training courses in protein energy malnutrition under five years old. This result disagreed with Mogahed (2011) who presented that The nurses' ages ranged between $20-30$ years, their education levels were varied with A bachelor level $(76 \%)$. This study also revealed that nurse's years of experience $>2$ year $(54 \%)$, and experience years less than 5 years (70.0\%).Also disagreed with Ahmed. et. al., (2009) who present in his study result.

The results of the study sample presents that most of the nurses in the study have poor knowledge in protein energy malnutrition for Children under age five years. Whereas $42.4 \%$ of them have poor Knowledge in concern to malnutrition in general, $48.5 \%$ of them have poor Knowledge in relation to types of malnutrition, acute and chronic malnutrition (wasting, stunting and Underweight), $45.5 \%$ of them have poor Knowledge about to nursing management of malnutrition, lack of protein and energy and at lastly $42.4 \%$ of them have poor knowledge in total knowledge score (Table 2). This result agreed with Yuna (2014) who presented the results of his study that the majority of health professionals had poor knowledge about malnutrition in children. Also agreed with Mogahed (2011) and Ahmed et al. (2009) presented in the results that the majority of health care workers (nurses) had poor knowledge of malnutrition.

The present study results of the present study show the mean of nurses knowledge in concern to malnutrition in general was (5.55) with standard deviation (1.938), the mean of nurse's knowledge in relation to types of malnutrition, acute and chronic malnutrition (wasting, stunting and underweight) was (5.18) with standard deviation (1.960), the mean of nurse's knowledge about to nursing management of malnutrition, lack of protein and energy was (5.61) with standard deviation (2.715) and lastly the mean of total knowledge score was (16.48) with standard deviation (5.455) (Table 3). This result agree with M.Kavitha, (2015) who presented in the study result that Overall and area wise distribution of mean, standard deviation and mean percentage of mothers of under five children regarding malnutrition shows that overall mean score 15.11 which is 65.59 percentage revealing average knowledge of mothers of under five children regarding malnutrition. Area wise knowledge scores reveals that highest mean score $15.5+2.09$ which is 67.7 percentage of mothers having knowledge on effects of malnutrition, mean score 15.4 which is 66.9 percentage of mothers having knowledge on prevention of malnutrition, mean score 14.3 which is 62.17 percentage of mothers having knowledge on malnutrition. Hence it can be interrupted most of mothers having knowledge in effects of malnutrition. Also agree with Yadav S.,, (2016) who presented In the study result that the mean of score was observed of total Knowledge score was (45.52) and SD was (18.07)

The results of the present study shows that there were significant differences between the age with nurse's knowledge about protein energy malnutrition for children under age five years that the p-value of age was (0.085), that there were significant differences between the educational level with nurse's knowledge about protein energy malnutrition for children under age five years that the p-value of educational level was $(0.025)$ also that there were significant differences between the years of general employments with nurse's knowledge about protein energy malnutrition for children under age five years that the p-value of years of general employments was $(0.065)$ but there were no significant differences between other parts of socio- demographic characteristics with nurse's knowledge about protein energy malnutrition for children under age five years at $p \geq 0.05$ value (Table 4). The result of this study disagree with Yadav (2016) who presented In the study that 
there was no statistically significant association found between the knowledge scores among mother of under five children regarding protein energy malnutrition and the demographic variables such as age, religion, type of family, income, occupation, under five children in family, immunization status of children and source of healthinformation at 0.05 level of significance, but agree with result of same study that presented statistically significant association found in level of education.

\section{CONCLUSION}

Based on the results of the present study, concluded that the majority of nurses were female at age 26-35 years old, graduated from Junior Nursing, have (1-7) years of general experience and inside experience in the medical pediatric wards, lastly high percent of nurses participated in training courses about protein energy malnutrition. Also high percent of nurses have poor knowledge about Kwashiorkor, marasmus, and nursing management of protein energy malnutrition. There is significant differences between age, level of education, and years of general employments with nurses Knowledge about protein energy malnutrition , but there is no significant differences between the gender, marital status, years of experiences in medical pediatric wards and participation in training courses with nurses Knowledge about protein energy malnutrition at $\mathrm{P} \geq 0.05$ value.

\section{RECOMMENDATION}

A continuous extensive special programs, training courses and workshops about protein energy malnutrition for children under age five years (classification or types, management and prevention procedure) should be designed and implement in hospital's departments to enhance the nurse's knowledge in regard to this major issue. Increasing the number of nurses, especially those who hold Bachelor degree in nursing to work in the medical pediatric wards for their ability and background. Further studies should be conducted on this issue covering a wide angle of the topic as well as covering large participants of nurses.

\section{REFRENCES}

Basavanthappa, B.T. (2011). Essential Of community health nursing. Jaypee Brothers med. Publisher (P) 1td, 1st Edition, New Delhi. P.p. 559.

SundarRao, Kasthuri.(2000). An Introdution to Child health Nursing. ( $3^{\text {rd }}$ ed.). IPuplication (P) Ltd, Newdelhi. P.p. 175.
Ahmed, Eiman; Mohamed, Saad; Sharif, Oshakahmed. (2016). Assessment Of Nurses' Knowledge And Practice Regarding Pneumonia In Children At AlmackNimer University Hospital Shendi Sudan,2009. The Malaysian Journal Of Nursing. 7(2). P.p. 21 - 26

Holmes, S. (2007). The effects of under nutrition in hospitalized patients. North America. P.p.90-102.

Iyengar, SD; Iyengar, K.; Gupta, V. (2009). Maternal Health. A Case Study of Rajasthan. J Health PopulNutr. 27(2). P.p. 92-271.

Park, K.(2005).Preventive and social medicine. (18 ${ }^{\text {th }}$ ed.).m/s.BanarsidasBhanot, Jabalpur.

Kavitha, M. (2015). Assess the Knowledge on Malnutrition among Mothers in Vinayaka Mission Hospital, Salem Vinayaka Missions Annapoorana college of Nursing, vinayaka missions university, salem. IOSR Journal of Nursing and Health Science (IOSR-JNHS). 4(4 Ver. VI) . P.p.27-35.

Mogahed, M. M. (2011). To Use ornotto Use Translation in Language Teaching. Translation Journal. 15(4).

Kumari, Neelam. (2016): "A text book of child Health Nursing-I". ( $1^{\text {st }}$ Ed.). S.Vikar\& co Puplishing House, Jalandhar. P.p. 495.

Hense, Sibasis. (2008). Health action-Innovative Interventions and health care, $\mathrm{MPH}$ pursuing southern cross university, Australia.

Susskind, D. (2009). Nutritional deficiencies during normal growth. Pediatric. North America. P.p.1035 -1053.

The Media and children's Rights. (2008). Millennium Development Goals. Connect World-Global Themes-Children. [Online] [Cited 2008 Nov 10].

Yadav, S. (2016). Knowledge and Practices regarding Prevention of Protein Energy Malnutrition among Mothers of under Five Children, Indian Nursing Council, SGT University. Asian Journal of Nursing Education and Research.6(1). P.p.96-100

Yuna, T. Hammond. (2014). Evaluating the Knowledge, Attitude and Practice of Rural Guatemalan Healthcare Providers Regarding Chronic Malnutrition in Children. Published thesis (MSc), Faculty of the Rollins School of Public Health of Emory University. P.p7-40. 